\title{
Escherichia coli RNase II: characterization of the promoters involved in the transcription of rnb
}

\author{
Rita Zilhão, ${ }^{1}$ Jacqueline Plumbridge, ${ }^{2}$ Eliane Hajnsdorf, ${ }^{2}$ \\ Philippe Régnier ${ }^{2}$ and Cećllia M. Arraiano ${ }^{1}$
}

\author{
Author for correspondence: Cecilia M. Arraiano. Tel: +351 1442 6321. Fax: +351 14428766. \\ e-mail: cecilia@itqb.unl.pt
}

1 Instituto de Tecnologia Química e Biológica, Universidade Nova de Lisboa, Apt 127, 2780

Oeiras, Portugal

2 Institut de Biologie Physico-Chimique, 13 rue Pierre et Marie Curie, 75005 Paris, France

\begin{abstract}
The rnb gene encodes ribonuclease II (RNase II), one of the two major Escherichia coli exonucleases involved in mRNA degradation. In this paper, the $\mathbf{m b}$ transcript is characterized regarding its promoter and terminator regions. The combined results from S1 nuclease protection analysis, DNase I footprinting and gene fusions with lacz have shown that $\mathbf{m b}$ is expressed from two promoters. $\mathrm{S} 1$ nuclease protection analysis and DNA footprinting have shown that rnb has two promoters, P1 and P2. Transcriptional and translational lacz reporter fusions, constructed to the $\mathbf{r n b}$ gene, revealed that P2, the rnb proximal promoter, is stronger than P1. However, P2 is not transcribed in vitro, suggesting that an additional factor is required in vivo. The 3 ' end of the rnb transcript mapped to a stem-loop structure immediately after the translated region.
\end{abstract}

Keywords: Escherichia coli, rnb, RNase II, promoters, transcriptional control

\section{INTRODUCTION}

Ribonucleases are one of the main factors that determine the level of functional messengers in the cell (Deutscher, 1988). Accordingly, in the last years much research has focused on the identification, description and possible regulation of endo- and exonucleases (Belasco, 1993). RNase II, a major processive exonuclease involved in $3^{\prime}-5^{\prime}$ mRNA degradation in E. coli (Kaplan \& Apirion, 1974; Donovan \& Kushner, 1986) was first described in 1963 (Spahr \& Schlessinger, 1963). Twenty years later the $r n b$ gene was cloned (Donovan \& Kushner, 1983), but the nucleotide sequence was only recently determined (Zilhão et al., 1993). Surprisingly, it has been suggested that RNase II may also have a stabilizing effect in the degradation of some messages (Hajnsdorf et al., 1994; Pepe et al., 1994). Strains carrying mutations like $r n b 296$, rnb500, $\Delta r n b 150:$ : tet and $\Delta r n b 201::$ tet are viable (Nikolaev et al., 1976; Donovan \& Kushner, 1986; Piedade et al., 1995; Zilhão et al., 1995a). However, double mutant strains ( $p n p 7 r n b 500$ ), deficient in RNase II and polynucleotide phosphorylase (PNPase, encoded by $p n p$ ) are not viable, suggesting that these two enzymes are functionally equivalent (Donovan \& Kushner, 1986). Non-viability of

The GenBank/EMBLDDBJ accession number for the corrected sequence of the $3^{\prime}$ end of $r n b$ is $X 67913$. the double mutant is most likely due to the lack of exonucleolytic activity suggesting that there are probably no nucleases that can replace the role of both RNase II and PNPase. However, in vitro studies have shown that these two enzymes have a different capacity to overcome secondary structures in mRNA (Guarneros \& Portier, 1990; McLaren et al., 1991). Other ribonucleases have been shown to be associated in complexes and to control their own expression (Miczak et al., 1991; Robert-Le Meur \& Portier, 1992; Carpousis et al., 1994). RNase II is post-transcriptionally regulated by RNase III and RNase E (Zilhão et al., 1995b). The possibility that RNase II could also be regulated at the level of transcription encouraged us to investigate the expression of the $r n b$ gene.

Based on a variety of in vitro and in vivo experimental approaches, we show that $r n b$ is transcribed from two promoters, P1 and P2, which have different expression levels. We suggest that in vivo RNA polymerase needs an additional factor to initiate at P2. In this paper we also report that the $r n b$ transcript terminates in a rhoindependent terminator as determined by $\mathrm{S} 1$ mapping and sequence analysis.

\section{METHODS}

Strains, plasmids, phages and media. E. coli strains and plasmids used in this work are listed in Table 1. The cultures 
Table 1. Bacterial strains, phages and plasmids

\begin{tabular}{|c|c|c|}
\hline $\begin{array}{l}\text { Strain, phage or } \\
\text { plasmid }\end{array}$ & Genotype and relevant markers & Source/origin \\
\hline \multicolumn{3}{|l|}{ Strain } \\
\hline JM101 & $\mathrm{F}^{-}\left(\right.$traD36 pro $A B$ lac $\left.I^{\mathrm{a}} Z \Delta \mathrm{M} 15\right)$ supE thi sbc-15 rpsJ end $A \Delta($ lac-pro $A B)$ & Yanisch-Perron et al. (1985) \\
\hline MG1693 & thy $A 715$ & Bachmann \& Low (1980) \\
\hline MC1061 & $\mathrm{F}^{-}$araD39 $\Delta($ ara-leu $) 7697 \Delta($ lac $) X 74$ galU galK bsdR rpsL str $A$ & Casadaban \& Cohen (1980) \\
\hline IBPC5321 & 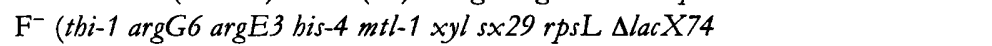 & Plumbridge et al. (1985) \\
\hline CMA162 & IBPC5321 גRZP02 & This work \\
\hline CMA163 & IBPC5321 $\lambda$ RZP03 & This work \\
\hline CMA164 & IBPC5321 $\lambda$ RZP04 & This work \\
\hline CMA165 & IBPC5321 $\lambda$ RZP05 & This work \\
\hline \multicolumn{3}{|l|}{ Phage } \\
\hline M13K07 & M13 helper & Vieira \& Messing (1987) \\
\hline$\lambda \mathrm{RS} 45$ & $b l a^{\prime}-l a c Z_{s c}, i m m-21$ ind $^{+}$ & Simons et al. (1987) \\
\hline$\lambda \mathrm{RZP} 02$ & As $\lambda$ RS 45 but with lac $Z$ transcriptional fusion to $0.6 \mathrm{~kb} P s t \mathrm{I}-S_{a l} / \mathrm{I}$ of $r n b$ & This work \\
\hline iRZP03 & As $\lambda$ RS45 but with lacZ transcriptional fusion to $0.36 \mathrm{~kb}$ Pst $\mathrm{I}-A s e \mathrm{I}$ of $r n b$ & This work \\
\hline$\lambda \mathrm{RZP04}$ & As $\lambda$ RS 45 but with lac $Z$ transcriptional fusion to $0.25 \mathrm{~kb}$ Ase I-SalI of $r n b$ & This work \\
\hline$\lambda \mathrm{RZP} 05$ & As $\lambda$ RS 45 but with lac $Z$ translational fusion to $0.6 \mathrm{~kb}$ PstI-SalI of $r n b$ & This work \\
\hline$\lambda \mathrm{RZP} 06$ & As $\lambda$ RS45 but with lacZ translational fusion to $0.25 \mathrm{~kb}$ AseI-Sall of $r n b$ & This work \\
\hline \multicolumn{3}{|l|}{ Plasmid } \\
\hline $\mathrm{pSK}(+)$ & $A p^{R}$ & Stratagene \\
\hline pT7T3 18U & $A p^{R}$ & Pharmacia \\
\hline pRS414 & $\mathrm{Ap}^{\mathrm{R}} \operatorname{lac} Z^{\prime} Y A$ & Simons et al. (1987) \\
\hline pRS415 & $\mathrm{Ap}^{\mathrm{R}} \operatorname{lac} Z Y A$ & Simons et al. (1987) \\
\hline pRS414/NM481 & pRS414 with the pNM481 polylinker & J. Plumbridge \\
\hline pCMA01 & $6.5 \mathrm{~kb}$ HindIII-XhoI fragment of pDK07 in HindIII-XboI site of $\mathrm{pSK}(+)$ & Zilhão et al. (1993) \\
\hline pRZA03 & $2.65 \mathrm{~kb}$ PvuII fragment of pCMA01 in HincII site of $\mathrm{pSK}(+)$ & Zilhão et al. (1993) \\
\hline pRZA10 & $3.7 \mathrm{~kb}$ DraIII-HindIII fragment of pCMA01 in EcoRV site of $\mathrm{pSK}(+)$ & Zilhão et al. (1993) \\
\hline pRZA11 & $\begin{array}{l}3.7 \mathrm{~kb} \text { Bam HI-HindIII fragment of pRZA10 in Bam HI-HindIII site of } \\
\mathrm{pKS}(+)\end{array}$ & Zilhão et al. (1993) \\
\hline pRZA12 & $0.6 \mathrm{~kb}$ Pst I-SalI fragment of pCMA01 in Pst I-SalI site of $\mathrm{pSK}(+)$ & Zilhão et al. (1993) \\
\hline pRZA16 & $1.5 \mathrm{~kb}$ DraI-DraI fragment of pCMA01 in HincII site of pSK $(+)$ & This work \\
\hline pRZA17/18 & $\begin{array}{l}\text { Two different orientations of the } 0.7 \mathrm{~kb} \text { Aat II-Aat II fragment from } \\
\text { pRZA16 in } 5 m a \mathrm{I} \text { site of pT7T3 }\end{array}$ & This work \\
\hline pRZA27 & $1.5 \mathrm{~kb}$ EcoRV-HindIII fragment of pRZA03 in SmaI-HindIII of $\mathrm{pKS}(+)$ & This work \\
\hline pRZP02 & $\begin{array}{l}0.6 \mathrm{~kb} \text { PstI-SalI fragment of pCMA01 in SmaI site of pRS415 (construction } \\
\text { transferred to } \lambda \mathrm{RS} 45 \text {; contains P1P2) }\end{array}$ & This work \\
\hline pRZP03 & $\begin{array}{l}0.36 \mathrm{~kb} \text { Pst } \mathrm{I}-\text { AseI fragment of PCMA01 in SmaI site of pRS415 } \\
\text { (construction transferred to } \lambda \mathrm{RS} 45 \text {; contains } \mathrm{P} 1 \text { ) }\end{array}$ & This work \\
\hline pRZP04 & $\begin{array}{l}0.25 \mathrm{~kb} \text { AseI-SalI fragment of pCMA01 in } S m a \mathrm{I} \text { site of pRS415 } \\
\text { (construction transferred to } \lambda \mathrm{RS} 45 ; \text { contains } \mathrm{P} 2 \text { ) }\end{array}$ & This work \\
\hline pRZP05 & $\begin{array}{l}0.6 \mathrm{~kb} \mathrm{BamHI}-E c o \mathrm{RI} \text { fragment of pRZP02 in Bam } \mathrm{HI}-E c o \mathrm{RI} \text { site of } \\
\text { pRS414/NM481 (construction transferred to } \lambda \mathrm{RS} 45 \text {; contains P1P2) }\end{array}$ & This work \\
\hline pRZP06 & $\begin{array}{l}0.25 \mathrm{~kb} \mathrm{BamHI}-E c o \mathrm{RI} \text { fragment of pRZP04 in BamHI-EcoRI site of } \\
\text { pRS414/NM481 (construction transferred to } \lambda \mathrm{RS} 45 \text {; contains P2) }\end{array}$ & This work \\
\hline
\end{tabular}

were grown at $30^{\circ} \mathrm{C}$ in Luria broth or Luria agar. Minimal MOPS/Tricine medium supplemented with $1 \mu \mathrm{g}$ thiamine $\mathrm{ml}^{-1}$, $0.4 \%(\mathrm{w} / \mathrm{v})$ glucose and $2 \mathrm{mM}$ potassium phosphate was used as specified below. When required, media were supplemented with $100 \mu \mathrm{g}$ ampicillin $\mathrm{ml}^{-1}$ and/or $40 \mu \mathrm{g} \mathrm{X-Gal} \mathrm{m} \mathrm{m}^{-1}$.

Plasmid DNA isolation and cloning procedures. Plasmid DNA isolation, cloning and transformation procedures were as described by Sambrook et al. (1989). Subcloning steps were usually performed by isolation of the desired fragments from agarose (Sigma) by electroelution. RNA polymerase and DNase I were from Boehringer Mannheim. Restriction enzymes were purchased from either Stratagene, Promega or Boehringer Mannheim, and were used under the conditions recommended by the supplier. Primers were synthesized with a Gene Assembler Plus (Pharmacia LKB).

S1 nuclease mapping on in vivo transcripts. Total RNA was isolated from exponentially growing cells by the hot-phenol method as described by Hajnsdorf et al. (1994). S1 nuclease protection experiments were performed according to the methods of Régnier \& Portier (1986). The $0.6 \mathrm{~kb}$ Pst $\mathrm{I}-\mathrm{Sal}$ DNA fragment (Fig. 2a, bottom), used for $5^{\prime} \mathrm{S} 1$ nuclease mapping was $5^{\prime}$ end-labelled with polynucleotide kinase, as 
(a)

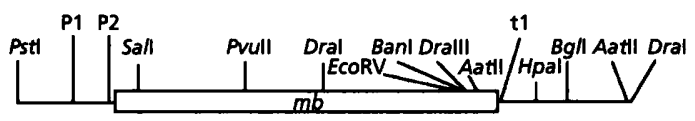

(b)
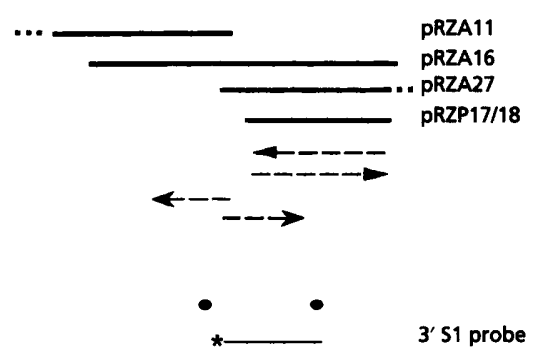

(c)

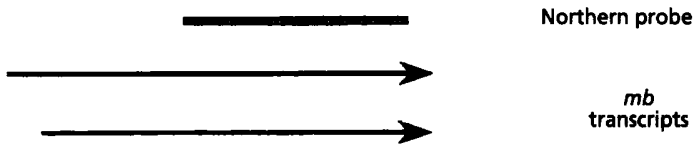

Fig. 1. (a) Features of the $r n b$ genetic region. The open box represents the structural part of the $r n b$ gene. P1, P2 and $t 1$ locate the two promoters and the rho-independent terminator characterized in this work. Only relevant restriction sites are given. (b) Chromosomal DNA fragments used to construct plasmids for the determination of $r n b 3^{\prime}$ nucleotide sequence are shown. Broken arrows indicate the direction and the length of the sequences determined from pRZA11, pRZA17, pRZA18 and PRZA27 (see Methods). The position of primers used in the amplification of the DNA fragment used to construct the $3^{\prime}$ S1 probe is indicated by two black circles. The $3^{\prime} \mathrm{S1}$ probe is represented by a line and a star at its labelled $3^{\prime}$ end. (c) Shaded box represents Northern blot probe made from pRZA10 (see Methods). Extent of $r n b$ transcripts deduced from in vivo and in vitro experiments is represented by black arrows.

described by Zilhão et al. (1993). To construct the 3' S1 mapping probe, a DNA fragment of 595 bp covering the $3^{\prime}$ end and the region downstream of $r n b$ was synthesized by PCR. The sequences of the upstream and downstream primers were $5^{\prime}$ CGCTTCCTGAAAGACAAAGCC $3^{\prime}$ and 5' ATCGCTGCTTCCGTCAACCG 3', respectively. After phenol extraction and ethanol precipitation the amplified fragment was digested with BanI and the large $0.48 \mathrm{~kb}$ DNA fragment was purified. The recessed $3^{\prime}$ end was filled and labelled with the Klenow fragment of DNA polymerase I and $\left[\alpha_{-}{ }^{32} \mathrm{P}\right] \mathrm{dGTP}$ (Fig. 1b) (Sambrook et al., 1989). In all experiments the probe was in excess, so that the amount of protected fragments was proportional to the RNA added. Sequencing reactions products from M13 phage or a $5^{\prime}$ end-labelled $1 \mathrm{~kb}$ ladder (Gibco, BRL) were run in parallel to estimate the size of the protected fragments.

Transcription in vitro and DNase I footprinting. Transcription in vitro using $500 \mathrm{ng}$ of the $0.6 \mathrm{~kb}$ Pst $\mathrm{I}-$ SalI DNA fragment (Fig. 2b, bottom) was performed as described by Régnier \& Grunberg-Manago (1989) using 0.5 U RNA polymerase. The reaction mixtures were extracted with phenol/chloroform, ethanol precipitated and electrophoresed on a $6 \%(\mathrm{w} / \mathrm{v})$ denaturating polyacrylamide gel together with the labelled $1 \mathrm{~kb}$ BRL molecular mass marker.

The same $0.6 \mathrm{~kb}$ PstI-SalI DNA fragment was $5^{\prime}$ end-labelled with $\left[\gamma^{32} \mathrm{P}\right] \mathrm{ATP}$ and T4 polynucleotide kinase and then digested with FspI to obtain a DNA fragment labelled only at the SalI 5' end (Fig. 2c, bottom). The labelled fragment (100 ng) was mixed with $1 \mathrm{U}$ purified RNA polymerase in $25 \mu \mathrm{l}$ binding buffer ( $25 \mathrm{mM}$ HEPES, $50 \mathrm{mM}$ glutamate), $0.5 \mathrm{mg} \mathrm{BSA} \mathrm{ml^{-1 }}$ and $10 \mathrm{mM} \mathrm{MgCl}$ in a final volme of $40 \mu \mathrm{l}$. After $15 \mathrm{~min}$ incubation at $37^{\circ} \mathrm{C}, 0.4 \mathrm{ng}$ DNase I (freshly diluted in $10 \mathrm{mM}$ Tris/ $\mathrm{HCl}, \mathrm{pH} 8.0,10 \mathrm{mM} \mathrm{MgCl}, 10 \mathrm{mM} \mathrm{CaCl}_{2}, 125 \mathrm{mM} \mathrm{KCl}$, $0.1 \mathrm{mM}$ DTT) was added, and the incubation was continued for $1 \mathrm{~min}$. Since $\mathrm{Mg}^{2+}$ is needed for RNA polymerase to bind, two control reactions in the absence of the polymerase were included to see if pre-incubation with $\mathrm{Mg}^{2+}$ alters the DNase I pattern. Reactions were terminated by the addition of $200 \mu$ l of DNase I stop buffer (0.4 M sodium acetate, $\mathrm{pH} 4.5,2.5 \mathrm{mM}$ EDTA, $5 \mu \mathrm{g}$ salmon sperm DNA ml ${ }^{-1}$ ) and $100 \mu$ phenol. The mixtures were precipitated with ethanol and cleavage products were separated on a $6 \%(\mathrm{w} / \mathrm{v})$ polyacrylamide gel together with pBR322 digested with $M s p \mathrm{I}$ as a molecular mass marker.

Northern blot. RNA samples $(10 \mu \mathrm{g})$ dissolved in MOPS formamide/formaldehyde buffer (Sambrook et al., 1989), were heated for $10 \mathrm{~min}$ at $70^{\circ} \mathrm{C}$, chilled on ice and fractionated on $1 \%(\mathrm{w} / \mathrm{v})$ agarose/formaldehyde gel in $1.5 \times$ MOPS buffer for $6 \mathrm{~h}$ at $80 \mathrm{~V}$ before being blotted to Amersham Hybond-N membranes (Sambrook et al., 1989). RNA was covalently bound to the membrane by UV irradiation and hybridized with the 1:1 kb PvuII [ $\alpha-{ }^{32}$ P]UTP-labelled antisense RNA transcript probe. The procedure for preparing the probe was essentially as described in the Promega technical bulletin using $1 \mu \mathrm{g}$ template plasmid pRZA10 (Table 1) linearized with PvuII.

DNA sequencing. Plasmids pRZA17 and pRZA18 were constructed by subcloning, in the two different orientations, the $0.7 \mathrm{~kb}$ AatII-AatII fragment of pRZA16 (Table 1 and Fig. 1) in pT7T3 18U digested by SmaI. Plasmid pRZA27 (Fig. 1) was constructed by subcloning the $1.5 \mathrm{~kb}$ EcoRV-HindIII fragment of pRZA03 between the SmaI and HindIII sites of pSK $(+)$ (Table 1 and Fig. 1). ssDNA was synthesized in strain JM101 after superinfection with the helper phage M13K07. DNA sequences were determined by the dideoxy method (Sanger et al., 1977), using T7 DNA polymerase Sequenase version 2.0 (USB) and $\left[\alpha^{35}\right.$ S $] \mathrm{dATP}$.

Construction of $r n b-l a c z$ fusions. Single-copy reporter gene fusions were constructed using the system developed by Simons et al. (1987) (Fig. 4). For transcriptional fusions the purified $0.6 \mathrm{~kb}$ PstI-SalI fragment from pCMA01, containing P1 and P2 $r n b$ promoter sequences, and the $0.36 \mathrm{~kb} P s t \mathrm{I}-A s e \mathrm{I}$ and $0.25 \mathrm{~kb}$ AseI-SalI sub-fragments, containing either $\mathrm{P} 1$ or $\mathrm{P} 2$, respectively, were inserted into pRS415 digested with $S \mathrm{maI}$ to give plasmids pRZP02, pRZP03 and pRZP04 (Fig. 4a). T4 DNA polymerase and dNTP were used to generate blunt ends in all fragments before ligation. After transformation, MC1061 containing these plasmids were selected as blue colonies on LB plates containing ampicillin and X-Gal. Several examples of each construction were tested and the clones selected were representative of the three fragments cloned in the same direction as the $l a c Z$ gene. Translational $r n b-l a c Z$ fusions were obtained by subcloning into pRS414/NM481 the EcoRI-BamHI fragments from pRZP02 and pRZP04, containing P1 plus P2, and $P 2$, respectively. These constructions gave rise to plasmids pRZP05 and pRZP06 (Fig. 4b). In pRS414/NM481 (J. Plumbridge, unpublished results), the polylinker region of pRS414 has been replaced by the translational phasing restriction sites of pNM481 (Minton, 1984) (Table 1). In plasmids pRZP05 and pRZP06, the first 37 codons of $r n b$ are in the same reading frame as the 9 th codon of this $\triangle \mathrm{ATG}-$ lac $Z$ plasmid. Colony selection of in-phase translational fusions was performed as indicated above. The resulting plasmids pRZP02, pRZP03, 
(a)
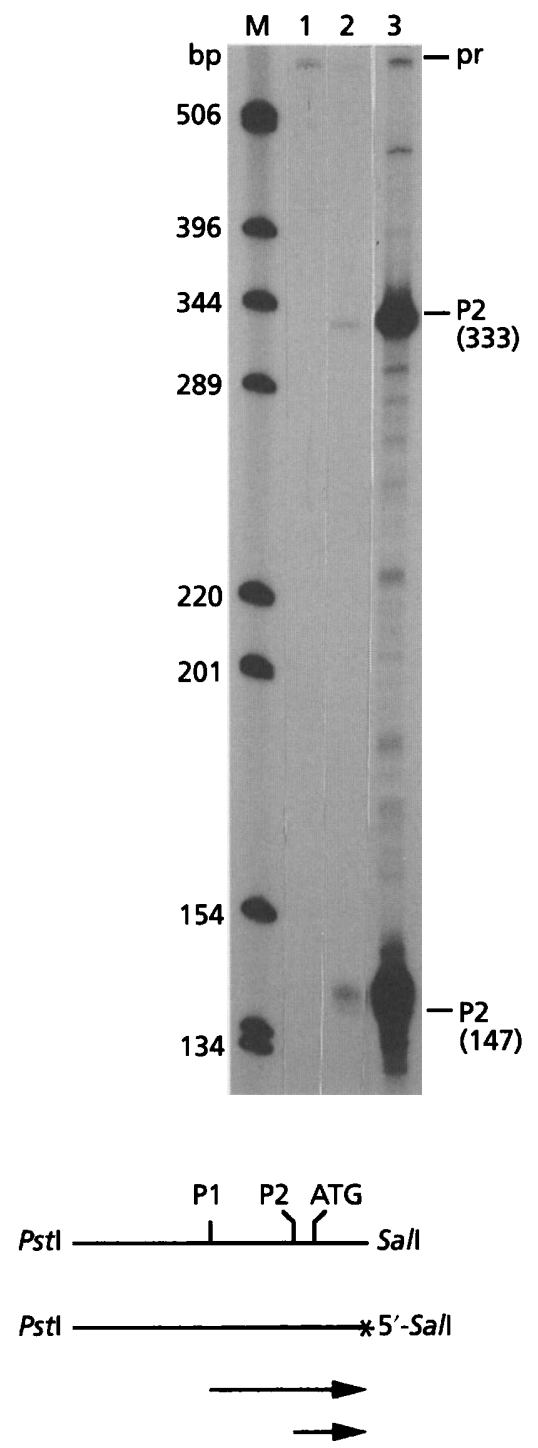

(b)

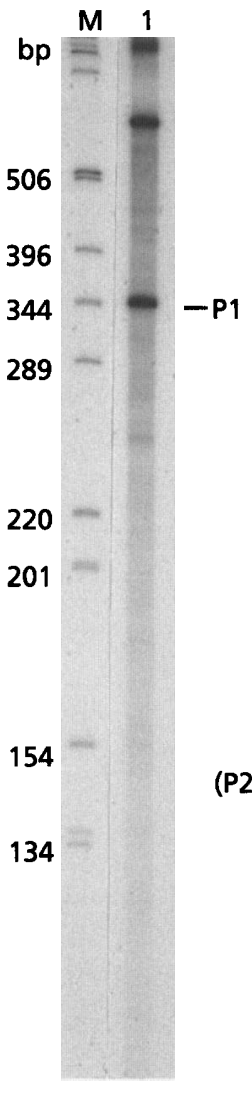

(P2)

110

(c)
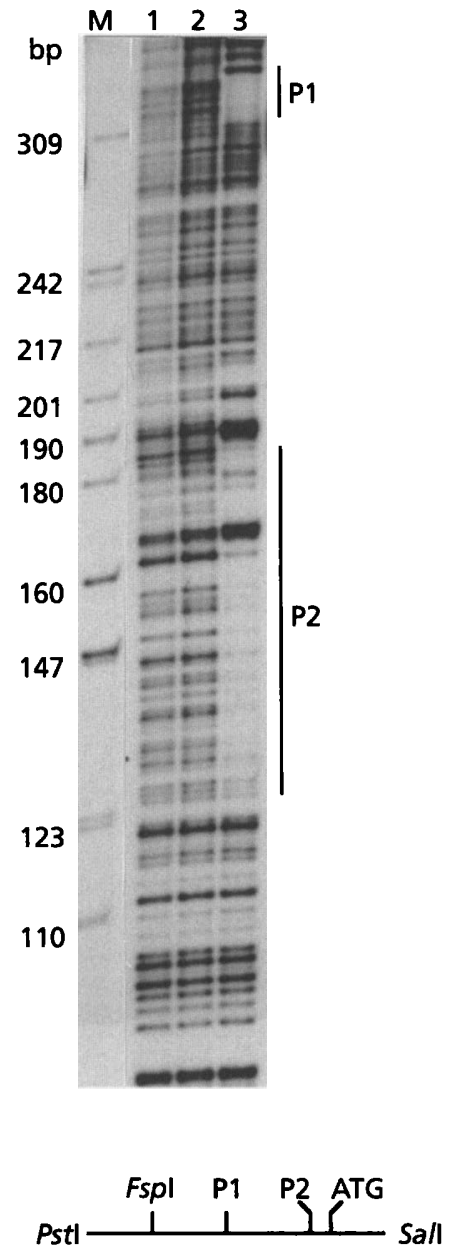

Fspl $\longrightarrow 5^{\prime}-$ Sall

Fig. 2. Promoter mapping of $r n b$ gene. (a) Total RNA (15 $\mu \mathrm{g}$ ) from the wild-type strain MG1693 (lane 2) and MG1693 transformed with pCMA01 plasmid (lane 3), were analysed by $\$ 1$ nuclease mapping with the $5^{\prime}$ end-labelled Pstl-Sall probe as shown at the bottom. Lane 1 corresponds to a control experiment in which mRNA is substituted by tRNA. Sizes of DNA markers (lane $M$ ) are indicated on the left. The lengths of protected fragments, in bp shown on the right side of the picture, localize the $5^{\prime}$ extremities of transcripts at P1 and P2 promoters (see bottom). 'pr' shows the location of the probe. (b) RNA synthesized in vitro using the Pstl-Sall fragment as a template and 0.5 U RNA polymerase (lane 1). Lane M, 5 ' end-labelled marker DNA fragments. P1 indicates the position of the run-off RNAs whose lengths correspond to transcripts initiated at $P 1$ and terminated at Sall. (P2) indicates the expected position of the run off RNA transcript originating from P2. The DNA fragment used as a transcription template is represented by a thick line and the resulting transcript as a shaded box (see bottom). (c) The 409 bp Fspl-Sall DNA fragment labelled at the $5^{\prime}$ end (see bottom) was incubated with $1 \mathrm{U}$ purified RNA polymerase and digested with DNase I (lane 3). The protected regions corresponding to the binding of RNA polymerase at P1 and P2 are indicated on the right-hand side of the gel and at the bottom as an interrupted line. Lane $M$, migration of the $5^{\prime}$ end-labelled size markers. Lanes 1 and 2 are DNase I digestion controls without RNA polymerase. In lane $1, \mathrm{Mg}^{2+}$ was added to the reaction (see Methods). Lane 3, DNase I digestion with $1 \mathrm{U}$ RNA polymerase.

pRZP04, pRZP05 and pRZP06, were subsequently transferred to the $\lambda$ RS45 vector by a double recombination event, as described by Simons et al. (1987). The phages carrying each construction, $\lambda \mathrm{RZP02}, \lambda \mathrm{RZP03}, \lambda \mathrm{RZP04}, \lambda \mathrm{RZP} 05$ and $\lambda \mathrm{RZP06}$ were lysogenized into IBPC5321 and used to determine the $r n b$ P1 and P2 promoter expression levels.
Overnight cultures of lysogens were subcultured and grown in Luria broth or MOPS at $30^{\circ} \mathrm{C}$. Aliquots were removed at $\mathrm{OD}_{650} 0.2$ and 0.4 and were assayed for $\beta$-galactosidase activity by the method of Miller (1972). Several lysogens from each construction were measured to determine $\beta$-galactosidase activities of monolysogens. 


\section{RESULTS}

\section{The rnb gene has two promoters}

S1 protection experiments with the $0.6 \mathrm{~kb}$ PstI-SalI $5^{\prime}$ end-labelled probe revealed after a short gel run two $5^{\prime}$ ends in the wild-type strain MG1693 (Fig. 2a). The same $5^{\prime}$ ends were obtained in the MG1693 strain transformed with the high-copy plasmid pCMA01, that contains the $r n b$ gene (Fig. 2a, top, lane 3). The $5^{\prime}$ end of the shorter transcript was mapped $333 \mathrm{bp}$ upstream of the initiation codon. Inspection of the DNA sequence identified a potential -10 promoter sequence (TACAAT) $5 \mathrm{bp}$ upstream of the mapped $5^{\prime}$ extremity with a potential -35 sequence (TTGAGC) $17 \mathrm{bp}$ further upstream (Zilhão $e t$ al., 1993). The $5^{\prime}$ end of the shorter transcript was mapped $186 \mathrm{bp}$ downstream of the extremity of the longer transcript and $31 \mathrm{bp}$ upstream from the structural gene (Fig. 3). A potential -10 sequence (TAAAAC) located $5 \mathrm{bp}$ upstream of this extremity and separated by $17 \mathrm{nt}$ from a -35 sequence (TTGCCG), could account for the transcription initiation at this site (Hawley \& McClure, 1983). Several experiments were performed to determine if this $5^{\prime}$ end corresponded to a promoter or to a processing site. Transcription in vitro of the $0.6 \mathrm{~kb}$ PstI-SalI fragment gave rise to a single transcript of approximately $333 \mathrm{nt}$. This agreed with the expected size of the runoff transcripts initiated at P1 (Fig. 2b, top). No species was detected which could account for initiation at P2. This suggested that the shorter transcript could be the result of processing of the longer transcript. However, DNase I footprinting analysis showed that RNA polymerase is capable of binding to both regions (Fig. 2c, top). Footprinting analysis was done with purified RNA polymerase and the $5^{\prime}$ labelled $0.4 \mathrm{~kb}$ Fs $p \mathrm{I}-$ SalI DNA fragment carrying the $\mathrm{P} 1$ and $\mathrm{P} 2$ putative $r n b$ promoters. According to the numbering of the $r n b$ sequence in Fig. 3, the two regions protected against DNase I attack by RNA polymerase binding span from $n t 27$ to 77 and from $n t 196$ to 261 . They agreed perfectly with the location of a

20 $\mathrm{Pl}$ TCATTCTGTTGAGCGCGCTACCGTTCAGGCGATACAATGGCTGACCCGAGCACCCGATCG 80 CTTTAGCGCCGCCCAGTTCAGCCCTTTACTCGAACACGAAAAATCATCAACGCAGATTAT 140 TAATCTGCTGGTATGGAGCGGGCTGTGTGGCTGGATAAATCGCTTAAAAATCGCGTTGGG $200 \quad$ P2 259 TGAGACATATTAACCITGCCGCGTCAGACAGATTCGCGTAAACTGTCAGCCGCTCTAAT 260
GGCCACCAAAATAGACAATTATGTT SD

Fig. 3. Sequence of the region encompassing the $r n b$ promoters. The proposed -35 and -10 regions of $P 1$ and $P 2$ are underlined and the nucleotides at the mapped RNA start points corresponding to these promoters are in bold letters. Putative Shine-Dalgarno sequence is indicated (SD) and the $r n b$ translation initiation start codon is in italics. Numbers correspond to the previously published sequence (Zilhăo et al., 1993). possible promoter consensus promoter sequence already proposed on the basis of the $\mathrm{S} 1$ nuclease analysis results (Figs 2a, top, and 3). It is worth noting that the footprint at P2 extends backwards as far as -70 from the transcription initiation site. Similar extended footprints have been observed at some other promoters, e.g. $\mathrm{rrnB}$ (Ross et al., 1993) and galP1 (Kolb et al., 1993; Attey et al., 1994). Taken together these results suggest that $r n b$ has two promoters but that RNA polymerase at P2 cannot initiate in vitro on this linear template and might require an additional factor, for example a supercoiled template or an accessory protein.

\section{Expression levels of $\boldsymbol{r n b} \mathbf{P} 1$ and $\mathbf{P 2}$ promoters}

To verify that $r n b$ has two functional promoters in vivo we constructed transcriptional fusions with the reporter gene lac $Z$. Three different $5^{\prime} r n b$ DNA fragments were used. One fragment carried both putative promoters and the others carried either P1 or P2 (Fig. 4a). The first 37 codons of $r n b$ are present in the constructions containing both P1 and P2 or P2 only. Translational fusions were also constructed (Fig. 4b; see Methods) to detect any transcriptional or translational regulatory effect operating at the $5^{\prime}$ end of $r n b$. The $r n b-l a c Z$ transcriptional and translational fusions were transferred to $\lambda \mathrm{RS} 45$ and the resulting phages were used to generate single-copy lysogens in the $\Delta l a c$ strain IBPC5321 (Table 1 and Fig. 4). These lysogens were designated CMA162, CMA163, CMA164, CMA165, and CMA166. $\beta$-Galactosidase activities measured during exponential growth of lysogens reflected the efficiency of the $\mathrm{P} 1$ and $\mathrm{P} 2$ promoters. Table 2 shows the $\beta$-galactosidase levels produced in Miller units (Miller, 1972). For each lysogen the same relative activities were found in the minimal glucose medium MOPS (data not shown) and in rich medium. Promoter P2 appears to be threefold stronger than P1 and their activities seem to be additive when $\mathrm{P} 1$ and $\mathrm{P} 2$ are both present. The same P2/P1P2 ratio obtained for translational and for transcriptional fusions suggested that transcripts originating at $\mathrm{P} 1$ and $\mathrm{P} 2$ are not subject to different translational/post-transcriptional regulation, at least not operating on the $r n b$ DNA region present in the $r n b-l a c Z$ fusions. The threefold lower $\beta$-galactosidase activities in translational fusions compared to transcriptional fusions might imply that $r n b$ is less well translated than $l a c Z$. It could also reflect a lower catalytic activity of the $r n b-l a c Z$ hybrid polypeptide.

\section{Location of the transcription termination site}

The lengths of the $r n b$ transcripts were determined by Northern blot analysis of total RNA (Fig. 1c). RNA of the wild-type strain MG1693 showed transcripts of about 2200 and $2000 \mathrm{nt}$ (Fig. 5). The size of these transcripts is sufficient to contain the $r n b$ gene. The difference in their length is compatible with the distance between P1 and P2, i.e. $180 \mathrm{bp}$ (Fig. 3). Similar results were obtained when the wild-type strain was transformed with the $r n b$ multicopy plasmid pCMA01 (Fig. 5, lane 2). Transcripts of this 


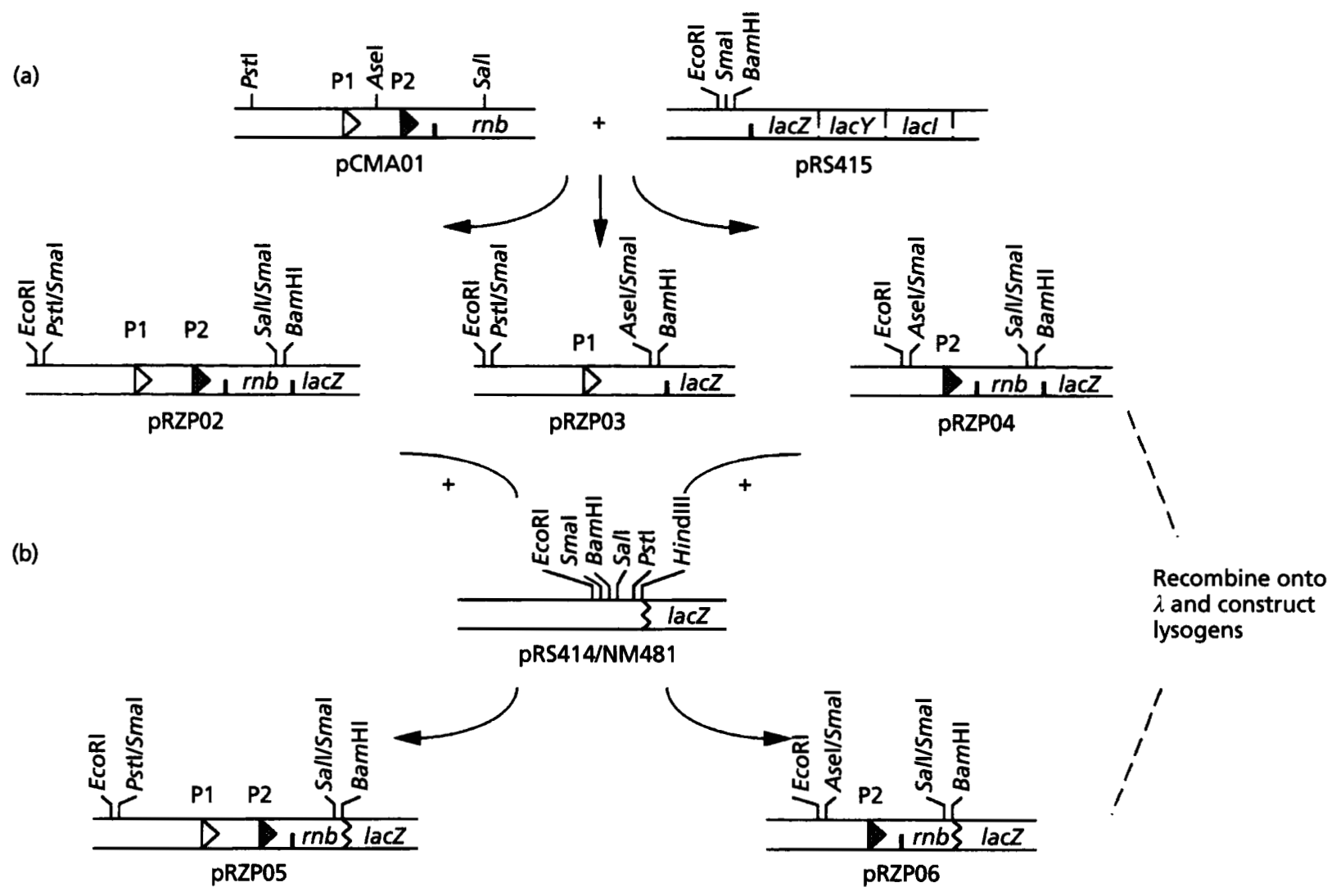

Fig. 4. Construction of plasmids and lysogens carrying rnb transcription and translation fusions with lacz. (a) Each of the three fragments, Pstl-Sall (containing P1 and P2), Pstl-Asel (containing P1) and Asel-Sall (containing P2), purified from PCMA01, were cloned in the correct orientation in relation to the lacZ gene, into the Smal site of the transcription fusion vector pRS415. This plasmid contains a lacZ gene with its own translation initiation site. (b) Cloning of the EcoRI-BamHI fragments from PRZP02 and PRZPO4 containing P1P2 and P2, respectively, in the translational fusion plasmid pRS414/NM481. The insertion is arranged so that the first 37 codons of the $r n b$ gene are fused in-frame to the 9 th codon of the lacZ gene. The $r n b-l a c Z$ fusions contained on all these plasmids were recombined onto $\lambda$ RS45 to generate five different phages, which were lysogenized in strain IBPC5321 (see text for further details). Only relevant restriction sites are indicated. The two rnb P1 and P2 promoters are indicated by arrowheads. Translation initiation codons of the genes are indicated in each construction by a vertical dash. The jagged lines at the beginning of the lac $Z$ gene indicate that it lacks its own translational initiation signals.

Table 2. $\beta$-Galactosidase activity of $r n b$ promoter-lacZ fusions

Single-copy lysogens carrying transcriptional and translational fusions of the promoter regions of $r m b$ to lac $Z$ were assayed for $\beta$-galactosidase activity as described in Methods. Cells were grown to exponential phase in Luria broth. The $\beta$-galactosidase activities, in Miller units, are the means of five independent assays.

\begin{tabular}{|c|c|c|c|c|c|}
\hline \multirow[b]{3}{*}{ Strain... } & \multicolumn{5}{|c|}{ Fusion type: } \\
\hline & \multicolumn{3}{|c|}{ Transcriptional } & \multicolumn{2}{|c|}{ Translational } \\
\hline & CMA162 & CMA163 & CMA164 & CMA165 & CMA166 \\
\hline Promoter region & P1P2 & $\mathrm{P} 1$ & P2 & P1P2 & P2 \\
\hline$\beta$-Galactosidase activity & 1215 & 164 & 898 & 390 & 270 \\
\hline
\end{tabular}

length predicted a $3^{\prime}$ end outside the previously sequenced region (Zilhão et al., 1993). Different plasmids (Table 1) were constructed to determine the nucleotide sequence of the $3^{\prime}$ end of the $r n b$ gene. A potential secondary structure, which exhibits a folding energy $(\Delta G)$ of $-38 \mathrm{kcal}$ $(159 \cdot 6 \mathrm{~kJ})$, is located $10 \mathrm{bp}$ downstream of the $r n b$ stop 


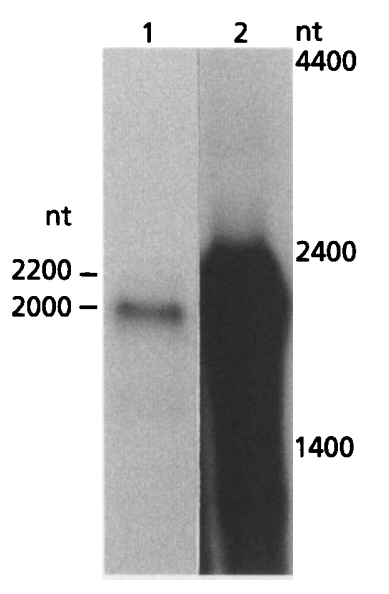

Fig. 5. Identification of $r n b$ transcripts. RNA $(10 \mu \mathrm{g})$ from the wild-type strain MG1693 (lane 1) and the pCMA01-transformed MG1693 cells (lane 2; in another experiment) were fractionated by electrophoresis on $1.5 \%$ agarose/formaldehyde, blotted to a nylon membrane and probed with the ${ }^{32} \mathrm{P}$-labelled antisense RNA probe illustrated in Fig. 1(c). An RNA ladder ranging from 330 to 9490 nt was run on a lane of the same gel which was cut out before blotting and stained with ethidium bromide. RNA size markers are given in nucleotides on the right of the picture. Positions and lengths of the two main $r n b$ transcripts are indicated on the left of the picture.

codon (Fig. 6b). This structure could correspond to a thoindependent terminator. S1 nuclease mapping was performed with a $3^{\prime}$-labelled BanI fragment covering the distal region of $r n b$ (Fig. 1b). A 201 bp protected DNA fragment was obtained which appears to correspond to a $3^{\prime}$ RNA end (Fig. 6a). This extremity maps to the stretch of Us following the potential transcription terminator ( $\mathrm{t} 1$ ) identified by the sequence data (Fig. 6b). Termination at this site of transcription initiated at P1 and P2 could account for the synthesis of the $2 \cdot 18$ and $2 \mathrm{~kb}$ transcripts identified on the Northern blots.

\section{DISCUSSION}

In this work, S1 mapping, DNase I footprinting, Northern blots and gene fusion experiments clearly establish that $r n b$ is transcribed from two promoters, P1 and P2. Consensus -10 and -35 sequences can be proposed for both of them (Fig. 3) (Hawley \& McClure, 1983). lacZ fusion experiments showed that both promoters are active in exponential cultures but have different expression levels (Table 2). P2, proximal to $r n b$ translation initiation site, is stronger than $\mathrm{P} 1$, and seems to account for $75 \%$ of total expression as suggested by transcriptional and translational fusions. A similar value for the relative strengths of the P1 and P2 promoters can be deduced from the intensities of the two fragments protected against S1 nuclease corresponding to the P1 and P2 transcripts (Fig. 2a, top). Since the level of $\beta$-galactosidase from P1 and P2 separately equals $\mathrm{P} 1$ plus $\mathrm{P} 2$ on the same fragment, it seems though that binding at P1 is probably not saturating the DNA template and that no promoter (a)

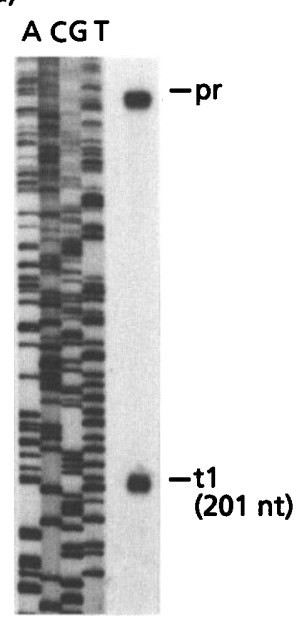

(b)

AGCCGTGGCGCCATCCGTGITCGTTTGGTTGATAAC

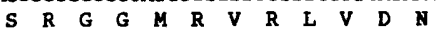

GGCGCTATCGCCITTATTCCGGCACCTTTCTTACAC $\begin{array}{lllllllllllll}G & \mathbf{A} & \mathbf{I} & \mathbf{A} & \mathbf{F} & \mathbf{I} & \mathbf{P} & \mathbf{A} & \mathbf{P} & \mathbf{F} & \mathbf{L} & \mathbf{H} & \end{array}$

GCTGTGCGOGATGAACTGGTTTCCAGCCAGGAAAAC $\begin{array}{llllllllllll}A & V & R & D & E & L & V & C & S & Q & E & N\end{array}$

GGCACTGTACAAATTAAAGGTGAAACGGTTTACAAA

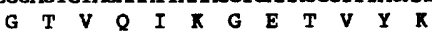

Fig. 6. Mapping of the $r n b$ terminator. (a) S1 nuclease protection mapping was carried out with a $0.48 \mathrm{~kb}$ DNA fragment, end-labelled at its Banl restriction site (Fig. 1b). The probe was hybridized with $20 \mu \mathrm{g}$ total RNA from the wild-type strain MG1693. The $201 \mathrm{nt}$ protected fragment is indicated by t1. Lanes $A, C, G$ and $T$ correspond to $M 13$ sequencing reactions used to estimate the size of the protected fragments. (b) Nucleotide sequence and deduced amino acid sequence of the $3^{\prime}$ end of $r n b$. The $r n b$ mRNA encodes a protein of a calculated molecular mass of $72484 \mathrm{Da}$. The TAA termination codon of $r n b$ is indicated by an asterisk. The potential secondary structure of the $r n b$ transcription terminator $(\Delta G=$ $-38 \mathrm{kcal} ;-159.6 \mathrm{~kJ}$ ) is shown (in the RNA structure Us replace Ts). The $3^{\prime}$ end ( $\left.t 1\right)$ of the $r n b$ message deduced from the S1 mapping experiment is indicated.

occlusion is detected. Intensity of the bands on Northern blot (Fig. 5), confirms that the shorter $r n b$ transcript initiated at P2 is more abundant than the longer P1 mRNA. However, in in vitro transcription experiments, only the transcript whose size corresponds to transcription initiation at P1 was observed (Fig. 2b, top). Despite the fact that no transcription from P2 promoter was observed in vitro with RNA polymerase holoenzyme, the corresponding region of the DNA is capable of binding RNA polymerase in vitro, as demonstrated by the production of a strong DNase I protection footprint (Fig. 2c, 
top). This binding could correspond to a 'closed' complex, based on -35 recognition. It is possible that RNA polymerase needs an additional factor to form an 'open' complex in vivo at P2. Therefore, transcription initiation at $\mathrm{P} 2$ might be positively regulated by a cofactor which interacts directly with the RNA polymerase and activates transcription (reviewed by von Hippel et al., 1984; Raibaud \& Schwartz, 1984; Collado-Vides et al., 1991; Ishihama, 1993).

The existence of two promoters implies some differential regulation of the $r n b$ gene at the level of transcription. Comparison of the results with the transcriptional and translational fusions did not give any evidence for a translational control of $r n b$ expression like that described for PNPase (Robert-Le Meur \& Portier, 1992). The relatively low $\beta$-galactosidase levels obtained from the $r n b-l a c Z$ translational fusions compared with those of transcriptional constructions (Table 2), suggest that $r n b$ might not be as efficiently translated as the lac $Z$ gene. This is consistent with the poor $r n b$ putative ribosome-binding (Shine-Dalgarno) site (Fig. 3) (Zilhão et al., 1993). The same P2/P1P2 ratios are obtained with translational and transcriptional fusions. This shows that P1 and P2 transcripts are translated into RNase II with the same efficiency.

The existence of a potential transcriptional terminator shows that transcription is probably stopped by a rhoindependent mechanism (Das, 1993) (Fig. 6). However, one can not rule out that this secondary structure functions as a stabilizing structure and readthrough transcripts are degraded up to t 1 by $3^{\prime}-5^{\prime}$ exonucleases (Platt, 1986). A similar mechanism was described for the tryptophan operon terminator trp-t (Mott $e t$ al., 1985).

In summary, the results obtained in this study indicate that the $r n b$ message is transcribed by two promoters and ends in a rho-independent terminator ten nucleotides downstream of rnb. The in vivo data clearly demonstrate that both promoters are really active. Interestingly, no in vitro transcription was found for the more efficient promoter $\mathrm{P} 2$. This suggests that an additional cis or trans factor, which remains to be determined, is involved in transcription activation. Experiments to elucidate the nature of this factor are in progress in our laboratory.

\section{ACKNOWLEDGEMENTS}

This work was supported by a cooperation between the Junta Nacional de Investigação Cientifica e Tecnológica (JNICT) and the French Embassy and the following grants: from JNICT (PMCT/C/BIO/875/90) to C.M. A.; from the University of Paris 7 (Contrat DRED) and from CNRS (URA1139) to P.R.; and from a network under the Human Capital and Mobility Programme (EEC) to P.R. and C.M.A. We gratefully acknowledge M. Grunberg-Manago and M. Springer for providing support and facilities. R.Z. was the recipient of a fellowship from the Gulbenkian Foundation.

\section{REFERENCES}

Attey, A., Belyaeva, T., Savery, N., Hoggett, J., Fujita, N., Ishihama, A. \& Busby, S. (1994). Interactions between the cyclic AMP receptor protein and the alpha subunit of RNA polymerase at the Escherichia coli galactose operon $\mathrm{P} 1$ promoter. Nucleic Acids Res 22, 4375-4380.

Bachmann, B. J. \& Low, K. B. (1980). Linkage map of Escherichia coli $\mathrm{K}-12$, edition 6. Microbiol Rev 44, 1-56.

Belasco, J. G. (1993). mRNA dgradation in prokaryotic cells: an overview. In Control of $m \mathrm{R} N A$ Stability, pp. 3-12. Edited by J. G. Belasco \& G. Brawerman. New York: Academic Press.

Carpousis, A. J., Van Houwe, G. Ehretsmann, C. \& Krisch, H. M. (1994). Copurification of E. coli RNase $E$ and PNPase: evidence for a specific association between two enzymes important for RNA processing and degradation. Cell 76, 889-900.

Casadaban, M. \& Cohen, S. N. . (1980). Analysis of gene control signals by DNA fusion and cloning in Escherichia coli. J Mol Biol 138, 179-207.

Collado-Vides, J., Magasanik, B. \& Gralla, J. D. (1991). Control site location and transcriptional regulation in Eschericbia coli. Microbiol Rev 55, 371-394.

Das, A. (1993). Control of transcription termination by RNAbinding proteins. Annu Rev Biochem 62, 893-930.

Deutscher, M. P. (1988). The metabolic role of RNases. Trends Biochem Sci 13, 136-139.

Donovan, W. P. \& Kushner, S. R. (1983). Amplification of ribonuclease II ( $r n b)$ activity in Escherichia coli K-12. Nucleic Acids Res 11, 265-275.

Donovan, W. P. \& Kushner, S. R. (1986). Polynucleotide phosphorylase and ribonuclease II are required for cell viability and mRNA turnover in Escherichia coli K-12. Proc Natl Acad Sci USA 83, $120-124$.

Guarneros, C. \& Portier, C. (1990). Different specificities of ribonuclease II and polynucleotide phosphorylase in $3^{\prime}$ mRNA decay. Biochimie 72, 771-777.

Hajnsdorf, E., Steier, O., Coscoy, L., Teysset, L. \& Régnier, P. (1994). Roles of RNase E, RNase II and PNPase in the degradation of the $r p s O$ transcripts of Escherichia coli: stabilizing function of RNase II and evidence for efficient degradation in an ams pnp rnb mutant. EMBO J 13, 3368-3377.

Hawley, D. K. \& McClure, W. R. (1983). Compilation and analysis of Escherichia coli promoter DNA sequences. Nucleic Acids Res 11, 2237-2255.

von Hippel, P. H., Bear, D. G., Morgan, W. D. \& McSwiggen, J. A. (1984). Protein-nucleic acid interactions in transcription: a molecular analysis. Annu Rev Biochem 53, 389-446.

Ishihama, A. (1993). Protein-protein communication within the transcription apparatus. $J$ Bacteriol 175, 2483-2489.

Kaplan, R. \& Apirion, D. (1974). The involvement of ribonuclease I, ribonuclease II, and polynucleotide phosphorylase in the degradation of stable ribonucleic acid during carbon starvation in E. coli. J Biol Chem 249, 149-151.

Kolb, A., Igarashi, K., Ishihama, A., Lavigne, M., Buckle, M. \& Buc, H. (1993). E. coli RNA polymerase, deleted in the C-terminal part of its $\alpha$-subunit, interacts differently with the cAMP-CRP complex at the lac $\mathrm{P} 1$ and at the gal 1 promoter. Nucleic Acids Res 21, 319-326.

Mclaren, R. S., Newbury, S. F., Dance, G. S. C., Causton, H. C. \& Higgins, C. F. (1991). mRNA degradation by processive $3^{\prime}-5^{\prime}$ exonucleases in vitro and the implications for prokaryotic mRNA decay in vivo. $J$ Mol Biol 221, 81-95.

Miczak, A., Srivastava, R. A. K. \& Apirion, D. (1991). Location of the RNA-processing enzymes RNase III, RNase E and PNPase in the Escherichia coli cell. Mol Microbiol 5, 1801-1810. 
Miller, J. H. (1972). Experiments in Molecular Genectics. Cold Spring Harbor, NY: Cold Spring Harbor Laboratory.

Minton, N. P. (1984). Improved plasmid vectors for the isolation of translational lac gene fusions. Gene 31, 269-273.

Mott, J. E., Galloway, J. L. \& Platt, T. (1985). Maturation of E. coli tryptophan operon: evidence for $3^{\prime}$ exonucleolytic processing after tho-independent termination. EMBO J 4, 1887-1891.

Nikolaev, N., Folsom, V. \& Schlessinger, D. (1976). Escherichia coli mutants in exoribonucleases. Biochem Biophys Res Commun 70, 920-924.

Pepe, C. M., Maslesa-Galic, S. \& Simons, R. W. (1994). Decay of the IS10 antisense RNA by $3^{\prime}$ exoribonucleases: evidence tht RNase II stabilizes RNA-OUT against PNPase attack. Mol Microbiol 13, 1133-1142.

Piedade, J., Zilhão, R. \& Arraiano, C. M. (1995). Construction and characterization of an absolute deletion mutant of Escherichia coli ribonuclease II. FEMS Microbiol Lett 127, 187-194.

Platt, T. (1986). 'Transcription termination and the regulation of gene expression. Annu Rev Biochem 55, 339-372.

Plumbridge, J. A., Dondon , J., Nakamura, Y. \& GrunbergManago, M. (1985). Effect of NusA protein on expression of the nus $A$, infB operon in E. coli. Nucleic Acids Res 13, 3371-3388.

Raibaud, O. \& Schwartz, M. (1984). Positive control of transcription initiation in bacteria. Annu Rev Biocbem 18, 389-446.

Régnier, P. \& Grunberg-Manago, M. (1989). Cleavage by RNase III in the transcripts of the met $Y$-nus $A$-infB operon of Escherichia coli releases the tRNA and initiates the decay of the dowstream mRNA. J Mol Biol 210, 293-302.

Régnier, P. \& Portier, C. (1986). Initiation, attenuation and RNase III processing of transcripts from the Escherichia coli operon encoding ribosomal protein S15 and polynucleotide phosphorylase. J Mol Biol 187, 23-32.

Robert-Le Meur, M. \& Portier, C. (1992). E. coli polynucleotide phosphorylase expression is autoregulated through an RNase IIIdependent mechanism. EMBO J 11, 2633-2641.
Ross, W., Gosink, K. K., Salomon, J., Igarashi, K., Zou, C., Ishihama, A., Severinov, K. \& Gourse, R. (1993). A third recognition element in bacterial promoters: DNA binding by the $\alpha$ subunit of RNA polymerase. Science 262, 1407-1413.

Sambrook, J., Maniatis, T. \& Fritsch, E. F. (1989). Molecular Cloning : a Laboratory Manual, 2nd edn. Cold Spring Harbor, NY: Cold Spring Harbor Laboratory.

Sanger, F., Nicklen, S. \& Coulson, A. R. (1977). DNA sequencing with chain-terminating inhibitors. Proc Natl Acad Sci USA 74, 5463-5467.

Simons, R. W., Houman, F. \& Kleckner, N. (1987). Improved single mutations and multicopy lac-based cloning vectors for protein and operon fusions. Gene 53, 85-96.

Spahr, P. F. \& Schlessinger, D. (1963). Breakdown of messenger ribonucleic acid by a potassium-activated phosphodiesterase from Escherichia coli. J Biol Chem 238, 2251-2253.

Vieira, J. \& Messing, J. (1987). Production of single-stranded plasmid DNA. Methods Enzymol 153, 3-11.

Yanisch-Perron, C., Vieira, J. \& Messing, J. (1985). Improved M13 phage cloning vectors and host strains: nucleotide sequences of the M13mp18 and pUC19 vectors. Gene 33, 103-119.

Zilhåo, R., Camelo, L. \& Arraiano, C. M. (1993). DNA sequencing and expression of the gene $r m b$ encoding Escbericbia coli ribonuclease II. Mol Microbiol 8, 43-51.

Zilhăo, R., Caillet, J. Régnier, P. \& Arraiano, C. M. (1995a). Precise physical mapping of the Escherichia coli mb gene, encoding the ribonuclease II. Mol \& Gen Genet 248, 242-246.

Zilhăo, R., Régnier, P. \& Arraiano, C. M. (1995b). The role of endonucleases in the expression of Eschericbia coli ribonuclease II. FEMS Microbiol Lett 130, 237-244.

Received 20 June 1995; revised 11 September 1995; accepted 27 September 1995. 